\title{
THE USE OF MUCOUS TRAILS BY INTERTIDAL LIMPETS TO ENHANCE FOOD RESOURCES
}

\author{
VALERIE M. CONNOR \\ Department of Zoology, University of California, Davis, California 95616, and The Bodega Marine \\ Laboratory, Bodega Bay, California 94923
}

\begin{abstract}
The mucous trails secreted by certain species of intertidal limpets serve as adhesive traps for the microalgae that are their primary food resources. The mucous trails of two solitary homing limpets, Lottia gigantea and Collisella scabra, also stimulate the growth of microalgae. In contrast, the mucous trails of an aggregating limpet, Collisella digitalis, and the carnivorous dog whelk, Nucella emarginata, do not stimulate microalgal growth. These results may be explained by differences in the behavior of these gastropod species. Homing species can capitalize on the production of a food enhancing mucus because they have restricted home ranges and retrace their own mucous trails.

The persistence time of mucus in the field varied with gastropod species, mucus type (i.e., mucus produced by moving or stationary limpets), and tidal height. Field studies suggest mucous trails can, but may not always, persist long enough to allow algal enhancement.

Biochemical analyses suggest that the ability of mucous trails to trap microalgae adhesively is correlated with carbohydrate content. The ability of mucous trails to stimulate microalgal growth is correlated with higher total organic content of mucous secretions and an ability to stimulate bacterial growth. A bacterial film may be important in the stimulation effect.
\end{abstract}

\section{INTRODUCTION}

As a gastropod crawls, it secretes a thin mucous layer that couples muscular movement to the substrate, thus powering locomotion while also permitting adhesion (Denny, 1980a; Grenon and Walker, 1980). A significant portion of a snail's energy budget $(7-26 \%)$ is devoted to pedal mucus production (Calow, 1974; Denny, 1980b) and pedal mucus production is associated with most gastropod activities (reviewed in Connor, 1983). Mucous trails function as chemical cues used to locate home sites, conspecifics, or established foraging routes (McFarlane, 1981). Pedal mucus also is involved in desiccation reduction (Wolcott, 1973), predator avoidance (Harrold, 1982), and home scar formation (Lindberg and Dwyer, 1983).

In this paper I elaborate on the evidence and mechanism for another function of limpet mucus, the involvement of mucus in the feeding ecology of limpets. Many species retrace and ingest mucous trails. These trails are adhesive and can trap microalgae that may serve as an additional food resource. In addition, certain species of homing limpets secrete mucous trails that stimulate the growth of the algal food spe-

Received 25 March 1986; accepted 25 September 1986. 
cies for later consumption, thus further supplementing the diet of the mucus producer (Connor and Quinn, 1984).

In a previous paper (Connor and Quinn, 1984) these phenomena were reported and explained in terms of the natural histories of the three limpet species studied. In the current study I extend the initial observations to evaluate the importance of a provendering ability under field conditions. First, to determine if algal enhancement is a unique property of the mucus produced by herbivores, the mucus of a carnivorous snail was examined. Second, the provendering abilities of pedal mucus were evaluated at a high and low intertidal site. The persistence of mucus at these sites also was monitored to determine whether mucous trails last long enough in the field for provendering effects to be significant. In addition to examining the importance of provendering abilities, this paper will focus on the potential mechanisms of microalgal biomass enhancement. First, the relationship between mucus type and bacterial growth rates was examined. A second approach was to determine the biochemical composition of the various mucus types and look for chemical components that varied among the species in ways corresponding to the species ranking patterns seen for microalgal adhesion, mucus persistence, or growth stimulation (microalgal and bacterial).

\section{MATERIALS AND METHODS}

\section{Experimental animals}

The provendering ability of mucous trails was examined in three species of acmaeid limpets found along the western coast of North America: Lottia gigantea Sowerby 1834 (hereafter referred to as Lottia), Collisella scabra (Gould) 1846, and Collisella digitalis (Rathke) 1833. All three are herbivores, grazing primarily on microalgae and encrusting algal forms. Lottia inhabits the high and mid-intertidal zones of exposed rocky coasts. It actively defends discrete territories from which it rarely ventures (Stimson, 1970, 1973; Sibley, 1982). It is a homing species, and characteristically returns to a home scar after all of its foraging activities.

Collisella scabra is a common inhabitant of the splash and upper intertidal zones. This limpet has been well studied, including its ability to home and form home scars (reviewed by Lindberg and Dwyer, 1983; Kunz and Connor, 1986). The ability of an individual C. scabra to retrace its own mucous trail in order to locate its home scar has been reported by Hewatt (1940); however, an individual does not have to retrace the outward trail to return home. Although the consistent return to a home scar increases limpet survival (Wells, 1980; Kunz and Connor, 1986), it also restricts the foraging range of C. scabra.

Collisella digitalis is another common inhabitant of the upper intertidal and splash zones. However, in contrast to both Lottia and C. scabra, C. digitalis does not form home scars. Collisella digitalis commonly forms large aggregations by following the mucous trails of conspecifics. Generally, $C$. digitalis does not home, and is more wide ranging in its foraging than either Lottia or C. scabra (Frank, 1964; Breen, 1972, 1973; Connor, 1983).

To help identify the functions of mucous secretions produced by herbivores, I also examined mucus function in a predatory gastropod, Nucella emarginata (hereafter referred to as Nucella). Nucella is a neogastropod that is found in the mid-intertidal zone and preys on barnacles and limpets (Abbott and Haderlie, 1980). 


\section{Animal maintenance}

Experiments were conducted from 1981 to 1983 at the Bodega Marine Laboratory, Sonoma County, California. All organisms used in experiments were collected from sites on or adjacent to the Bodega Bay Reserve, except Lottia which is not found at Bodega Bay. Lottia was collected near Santa Barbara or on San Nicolas Island, California. All animals were maintained in aquaria coupled to a flow-through seawater system. All snails were used within 48 hours of collection, except specimens of Lottia, which were used for up to two months after collection.

\section{Mucus collection}

Mucus was collected by rinsing limpets in seawater and positioning them on sloping glass plates. Limpets were placed at the bottom of plates and removed after they crawled to the top. In order to initiate movement, limpets were sprayed with seawater to simulate the incoming tide. The mucus produced by stationary limpets (hereafter called stationary mucus) is different in physical and chemical properties from trail mucus (Connor, 1983). The central portion of the plate contained primarily trail mucus and this mucus was removed with a razor blade. The potential for contamination of trail mucus with stationary mucus was greater in Lottia and C. scabra than in $C$. digitalis because these homing species are not as mobile as $C$. digitalis, and they often stopped moving. Nucella does not produce a distinct stationary mucus.

\section{Mucus as an adhesive trap for microalgae}

To determine differences in the adhesion of microalgae to the mucous trails of different gastropod species, trail mucus was collected from each species and spread evenly over one side of 12 Millipore filters ( $5 \mathrm{~cm}$ diameter). The mucus-coated filters were attached to Plexiglas sheets and suspended in battery jars filled with circulating microalgae cultures. Cultures contained a mixture of microalgal species (Fragilaria, Navicula, Coscinodiscus, Nitzschia, Achnanthes, Skeletonema, Synedra, Melosira, and two unidentified single-celled species of green algae) collected from the same field sites where limpets were collected. Microalgae were collected using the scrubbing technique of Nicotri (1974). Filters were exposed to the microalgal cultures for 18 hours in the dark (to minimize microalgal growth), after which the amount of microalgae adhering to the filters was estimated spectrophotometrically using the chlorophyll analysis technique of Strickland and Parsons (1968). Filters not coated with mucus also were placed in algal cultures to serve as a control. As an additional control, mucus-coated filters were placed in jars containing filtered seawater.

\section{Mucus as an algal growth stimulant}

To determine whether mucus acts as a microalgal growth stimulant, $1 \mathrm{ml}$ aliquots of the microalgal culture used in algal adhesion experiments were added to mucuscoated filters ( 10 filters per species) and uncoated control filters placed within Plexiglas wells ( $5 \mathrm{~cm}$ diameter). The filters were kept wet and incubated in continuous light (Gro-lights, General Electric). The filters were removed after seven days and algal biomass was determined as in the adhesion experiment. Preliminary experiments indicated that six days were required before a significant increase in microalgae was detectable. As an additional control, mucus-coated filters were placed in Plexiglas wells containing filtered seawater. 


\section{Field experiments}

Field experiments were conducted to determine the relevance of laboratory results to field conditions. Millipore filters coated with mucus and uncoated filters as controls (sample size ranged from 9 to 13 filters per treatment) were attached to Plexiglas panels and anchored vertically at the mouth of a semi-protected surge channel at $+1.7 \mathrm{~m}$ and $+.15 \mathrm{~m}$ above mean lower low water. The high site represents a typical habitat for all three limpet species. Macroscopic algae are rare at this level, but both Collisella species and barnacles (Balanus glandula) are abundant. The lower site was situated at a level below that normally inhabited by the three limpet species, although juveniles of all species $(<8 \mathrm{~mm})$ are found here within a highly diverse community of invertebrates and macroscopic algae.

The amount of microalgae adhering to the filters was determined after one day (high intertidal site only) and after seven days (both sites). The one-day experiment minimized time for algal growth and thus gave an estimate of the amount of algae adhesively trapped. The seven-day experiment measured the combined effects of adhesion and stimulation.

\section{Mucus persistence}

The field experiments combined the effects of mucous trails acting as adhesive traps and mucus acting as a microalgal growth stimulant. To determine whether mucous trails last long enough in the field for the stimulation effect to be significant (i.e., the seven days required in laboratory tests), a series of laboratory and field experiments examined the persistence of mucus.

Field tests. To measure mucus persistence in the field, individual gastropods were allowed to crawl over Plexiglas sheets for eight hours. All mucous secretions were clearly visible after the Plexiglas sheets were dipped in a suspension of carbon particles (decolorizing carbon) and rinsed in seawater. Trails and stationary mucus were outlined on the undersides of the Plexiglas sheets with a waterproof pen. The sheets were mounted on boards positioned at the same sites used in the field algal adhesion and stimulation experiments. A grid system was marked on each sheet and the specific types of mucus present within each grid cell $(5 \times 5 \mathrm{~cm}, \mathrm{n}=200$ cells per tidal height $)$ were noted. Mucus persistence was monitored each day by watching for the complete disappearance of the attached carbon particles from each grid cell. Mucus breakdown was assumed to be complete after all the carbon particles were in suspension.

Laboratory tests. To determine the persistence of mucus in the absence of wave action and variable tidal submergence, the technique of Calow (1979) was employed. Plastic petri dishes were filled with seawater and a single snail was placed in each dish for eight hours. Both mucous trails and stationary mucus were then coated with carbon particles. Both mucus types were outlined on the undersides of the dishes with a waterproof pen. Dishes were refilled with seawater and maintained at $11^{\circ} \mathrm{C}$. Each day, dishes were swirled and mucus persistence evaluated.

\section{Mucus as a bacterial growth stimulant}

Bacteria were collected by scrubbing intertidal rock surfaces and dipping the scrub brush into sterile seawater. The resulting water samples were filtered (Whatman \#2) to remove rock particles and microalgae, and vortexed to suspend the bacteria prior to inoculation.

Five mucus samples (50 mg wet weight) of each gastropod species were sterilized 
under U.V. light for 16 hours. Each sample was added to a sterile culture tube containing $3.5 \mathrm{ml}$ sterile TRIS buffer $(\mathrm{pH} 7.5)$ and $3.4 \mathrm{ml}$ sterile filtered seawater $(0.22$ micron Millipore filter). To four of the five samples for each species, a $0.1 \mathrm{ml}$ aliquot of bacteria suspension was added to each tube; sterile seawater was added as a control to the remaining tube. An additional control set of four test tubes contained bacteria, but no mucus. Tubes were sealed and placed in a test tube roller. After 44 hours, bacteria growth was determined qualitatively by recording the optical density of each test tube at $560 \mathrm{~nm}$ (Baumann and Baumann, 1980; Schwartzkoff et al., 1983).

\section{Biochemical characterization of mucus}

Trail mucus was collected and immediately lyophilized. Because all analyses were conducted with fresh freeze-dried mucus, the data include values for any material associated with the protein and carbohydrate components (as noted in Grenon and Walker, 1980). Values reported for each biochemical assay represent the average of three replicate samples.

Water content. Water content was determined from the weight difference between fresh and freeze-dried mucus. Sample weights were determined on a Cahn microbalance.

Inorganic content. Pre-weighed aliquots of freeze-dried mucus were ashed in a muffle furnace for five hours at $550^{\circ} \mathrm{C}$. The remaining inorganic residue content was calculated from the weight difference between pre- and post-ashed mucus samples.

Protein. The total protein content was determined using the micro Bio-Rad assay technique (Coomassie blue). Approximately $3 \mathrm{mg}$ mucus (dry weight) were homogenized in $80 \%$ ethanol and centrifuged at $10,000 \times g$ for 30 minutes. The pellets were dissolved in hot $1.0 \mathrm{~N} \mathrm{NaOH}$ and then assayed spectrophotometrically after the addition of Coomassie blue dye (Bradford, 1976). Bovine serum albumin (Bio-Rad) was used as a standard.

Carbohydrate. Ethanol-soluble and insoluble carbohydrate levels of $3 \mathrm{mg}$ mucus (dry weight) were measured by the micro-anthrone assay (Keleti and Lederer, 1973) using glucose as the standard.

Lipid. Lipid levels were determined by gravimetric measurement of lipid extracts. Approximately $3 \mathrm{mg}$ of mucus was homogenized with $0.5 \mathrm{ml}$ of distilled water. One $\mathrm{ml}$ of a chloroform-methanol solution (2:1) was added to the mucous homogenate which was then probe-sonicated (Biosonik III) for 30 seconds. Samples were centrifuged on a clinical centrifuge for two minutes at $2000 \mathrm{rpm}$ to separate the lipid-containing chloroform phase from the homogenate. After pipetting this layer into tared pans, the chloroform was evaporated and lipid weights were determined.

Free amino acids. Concentrations of free amino acids were determined using the fluorescamine assay for primary amines (North, 1975). A mucous sample $(0.5 \mathrm{mg})$

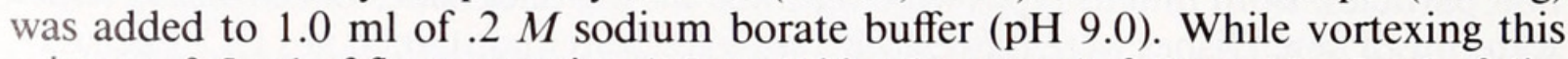
mixture, $0.5 \mathrm{ml}$ of fluorescamine $(15 \mathrm{mg} / 100 \mathrm{ml}$ acetone $)$, followed by $2 \mathrm{ml}$ of distilled water, were added to the sample. The fluorescence of each sample was determined on a spectrofluorometer with the excitation wavelength set at $390 \mathrm{~nm}$ and the ernission wavelength set at $480 \mathrm{~nm}$. Glycine was used as the standard.

\section{Statistical analyses}

Most experimental results were analyzed for interspecific differences in pedal mucus properties by an analysis of variance followed by mean separation tests (Student- 
Newman-Keuls multiple range test). Adhesion, stimulation, laboratory persistence, and bacteria growth data were log-transformed before analysis. Biochemical data were angular (arcsine) transformed before analysis. Means and standard errors presented in tables are untransformed values. At the end of 30 days, when the mucus field persistence experiment was terminated, there were still patches of mucus on the Plexiglas sheet located at the high intertidal site. Because the actual persistence time of these patches could not be estimated, nonparametric techniques using ranked persistence values were used to compare mucus types within the higher site and to compare the differences in persistence between the two tidal heights. The Kruskal-Wallis test and a nonparametric multiple comparison technique (Zar, 1974) were used in these comparisons.

\section{RESULTS}

\section{Mucus as an adhesive trap}

In the laboratory studies, the amount of microalgae adhering to pedal mucus varied significantly among the different gastropod species. Lottia, Nucella, and C. scabra produced trails that were not significantly different from each other $(P>.05)$ in terms of adhesion, but were more adhesive $(P<.05)$ than the trails of $C$. digitalis. The amount of algae adhering to $C$. digitalis trails was not significantly different $(P>.05)$ from the amount of microalgae adhering to the mucus-free surfaces of the control filters (Table I). No chlorophyll was detected on mucus-coated filters placed in battery jars containing algal-free seawater.

\section{Mucus as an algal growth stimulant}

In the laboratory study, chlorophyll analyses indicated a significantly higher $(P$ $<.05$ ) microalgal biomass on the trail mucus of Lottia and C. scabra than on the mucus of the other species. In addition, the microalgal biomass levels on Lottia trails were higher $(P<.05)$ than on $C$. scabra trails. Algal biomass on Nucella and $C$. digitalis samples was not significantly different $(P>.05)$ from levels measured for the mucus-free control filters (Table I). No chlorophyll was detected on mucus-coated filters that had been placed in algal-free seawater. Only the two solitary homing species, Lottia and C. scabra, produce a mucus with significant algal growth enhancement properties.

\section{Field experiments}

In the one-day field experiment it was assumed that the differences in the amounts of microalgal biomass attached to the filters were due primarily to differences in mucus adhesiveness. The amount of microalgae adhering to the mucous trails of all four gastropod species was significantly higher $(P<.05)$ than the amount of microalgae adhering to the mucus-free surfaces of the control filters (Table I). The overall trend suggests that Lottia and C. scabra have stickier mucous trails than C. digitalis, although the difference between $C$. scabra and $C$. digitalis was not significant $(P>.05)$. In contrast to the results of the laboratory adhesion experiments, there was no difference $(P>.05)$ between $C$. digitalis and Nucella trails in attached microalgae (Table I).

The seven-day field experiment was conducted at both high and low intertidal heights. Filters coated with mucus from all three limpet species had greater microalgal 


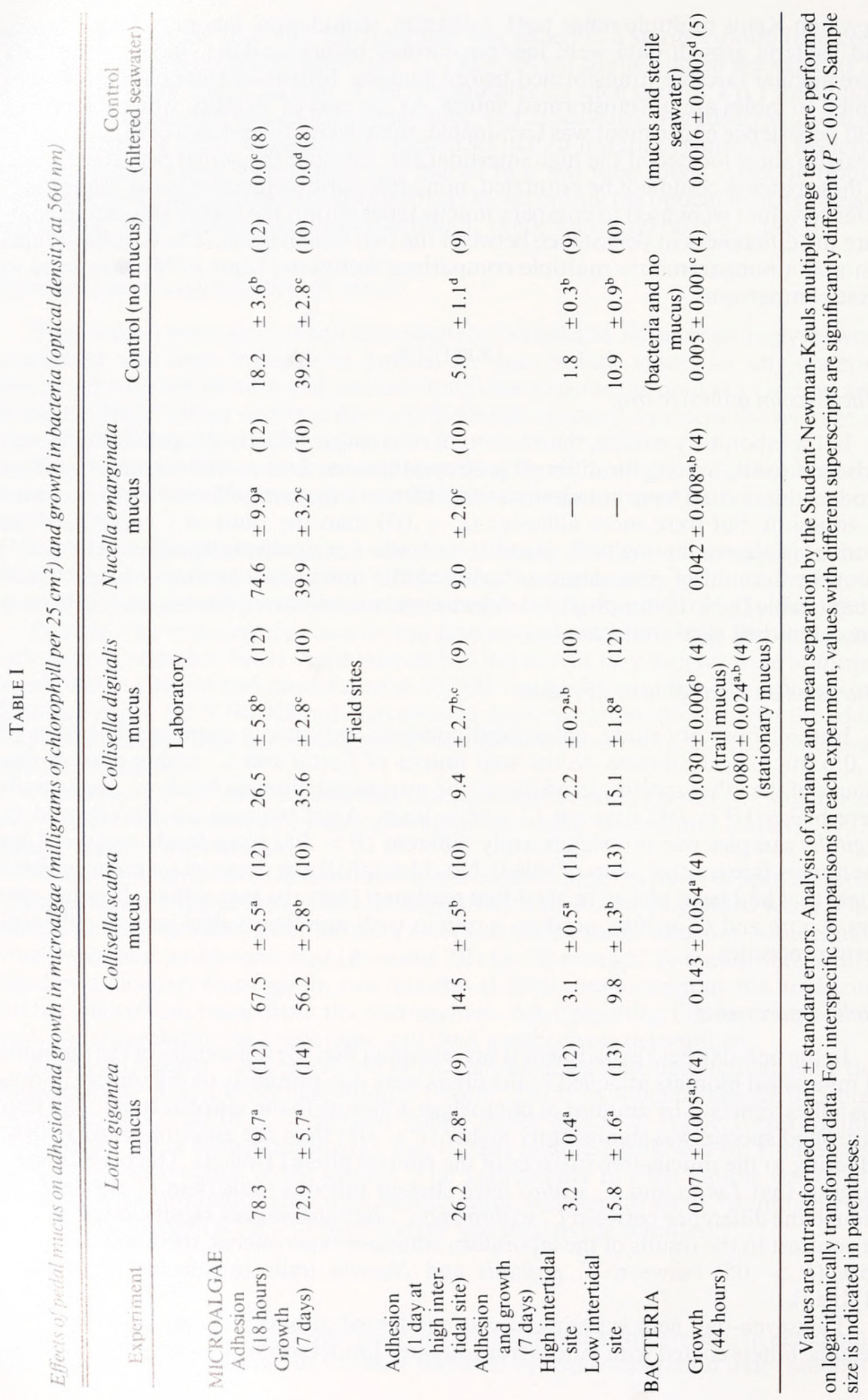


TABLE II

Persistence time (days) of trail and stationary pedal mucus

\begin{tabular}{|c|c|c|c|c|c|c|c|}
\hline \multirow[b]{2}{*}{ Experiment } & \multicolumn{2}{|c|}{ Lottia gigantea mucus } & \multicolumn{2}{|c|}{ Collisella scabra mucus } & \multicolumn{2}{|c|}{ Collisella digitalis mucus } & \multirow{2}{*}{$\begin{array}{c}\begin{array}{c}\text { Nucella } \\
\text { emarginata } \\
\text { mucus }\end{array} \\
\text { Trail }\end{array}$} \\
\hline & Trail & Stationary & Trail & Stationary & Trail & Stationary & \\
\hline Laboratory & $\begin{array}{c}11.2 \pm 1.0^{\mathrm{a}} \\
(18)\end{array}$ & $\begin{array}{c}7.3 \pm 0.4^{b} \\
(33)\end{array}$ & $\begin{array}{c}17.8 \pm 0.6^{\mathrm{c}} \\
\quad(11)\end{array}$ & $\begin{array}{c}9.1 \pm 0.6^{d} \\
(29)\end{array}$ & $\begin{array}{c}18.8 \pm 1.4^{\mathrm{c}} \\
(16)\end{array}$ & $\begin{array}{c}6.2 \pm 0.4^{b} \\
(25)\end{array}$ & $\begin{array}{c}20.1 \pm 1.3^{\mathrm{c}} \\
(20)\end{array}$ \\
\hline $\begin{array}{l}\text { High intertidal } \\
\text { site }\end{array}$ & $\begin{array}{c}15.2 \pm 1.4^{\mathrm{a}} \\
(30)\end{array}$ & $\begin{array}{c}23.5 \pm 1.5^{b} \\
(36)\end{array}$ & $\begin{array}{c}10.3 \pm 1.8^{c} \\
(18)\end{array}$ & $\begin{array}{c}16.8 \pm 2.3^{\mathrm{a}} \\
(16)\end{array}$ & $\begin{array}{c}10.3 \pm 1.1^{c} \\
(29)\end{array}$ & $\begin{array}{c}19.8 \pm 2.7^{d} \\
(16)\end{array}$ & $\begin{array}{c}12.9 \pm 1.6^{c} \\
(35)\end{array}$ \\
\hline $\begin{array}{l}\text { Low intertidal } \\
\text { site }\end{array}$ & $\begin{array}{c}5.0 \pm 0.2^{\mathrm{a}, \mathrm{b}} \\
(34)\end{array}$ & $\begin{array}{c}5.0 \pm 0.4^{\mathrm{a}, \mathrm{b}} \\
(36)\end{array}$ & $\begin{array}{c}4.0 \pm 0.3^{\mathrm{a}} \\
(17)\end{array}$ & $\begin{array}{c}7.5 \pm 0.7^{c} \\
\text { (13) }\end{array}$ & $\begin{array}{c}5.5 \pm 0.3^{b, d} \\
\text { (31) }\end{array}$ & $\begin{array}{c}6.8 \pm 0.4^{\mathrm{c}, \mathrm{d}} \\
(12)\end{array}$ & $\begin{array}{c}6.6 \pm 0.4^{\mathrm{c}, \mathrm{d}} \\
(33)\end{array}$ \\
\hline
\end{tabular}

Values are means \pm standard errors. For interspecific comparisons in each experiment, values with different superscripts are significantly different $(P<0.05)$. Sample size is indicated in parentheses.

biomass than the mucus-free control filters, although significant differences $(P<.05)$ were detected only for Lottia and C. scabra. The species ranking pattern of the amount of microalgal growth enhancement seen in the laboratory was reproduced at the high intertidal site. As before, there was a trend with Lottia having the highest microalgal biomass levels, followed by C. scabra, and then C. digitalis (Table I).

The results from the low intertidal zone were different from those obtained in both the high site and from the laboratory experiments. First, compared to the high site, there were significantly higher $(P<.05)$ levels of microalgal biomass across all treatments. Second, microalgal biomass levels were higher $(P<.05)$ on Lottia and $C$. digitalis mucus samples than on filters coated with $C$. scabra mucus or uncoated control filters (Table I). The levels of microalgal biomass for all treatments in the 1-day experiment were greater than biomass levels in the 7-day experiment.

\section{Mucus persistence}

Field experiments. The number of days that mucus persisted varied with tidal height, gastropod species, and mucus type (i.e., trail or stationary mucus) (Table II). Both stationary and trail mucus lasted longer $(P<.05)$ at the high site for all species. Considering persistence results from just the high site, the median persistence time for the trails of all species is at least seven days; presumably sufficient time to effectively stimulate microalgal growth. The trails of Lottia lasted significantly longer $(P<.05)$ than the trails of the other species, none of which were significantly different $(P>.05)$ from each other in persistence time. The stationary mucus produced by all three limpet species lasted significantly longer $(P<.05)$ than their trails. The stationary mucus produced by Lottia lasted significantly longer $(P<.05)$ than the stationary mucus produced by the other two limpet species.

At the low intertidal site, trail persistence times ranged from an average of 4.0 days for C. scabra to 6.6 days for Nucella. Stationary mucus persistence ranged from an average of 5.0 days in Lottia to 7.5 days in C. scabra. Collisella scabra trails disappeared the most rapidly, but not significantly more so than the trails and stationary mucus of Lottia. Lottia stationary mucus lasted longer than any other mucus type at the high intertidal site, but was one of the first mucus types to disappear at the low intertidal site (Table II). 
TABLE III

Summary of the biochemical composition of mucous trails

\begin{tabular}{lccccc}
\hline & Lottia & C. scabra & C. digitalis & Nucella & Significance \\
\hline Proportion of dry weight: & & & & & \\
$\quad$ Inorganics & $.430 \pm .020$ & $.470 \pm .015$ & $.450 \pm .025$ & $.757 \pm .013$ & $\underline{\mathrm{N}} \underline{\mathrm{SDL}}$ \\
Lipids & $.003 \pm .003$ & $.004 \pm .001$ & $.008 \pm .005$ & $.002 \pm .002$ & $\underline{\mathrm{DSLN}}$ \\
Carbohydrates & $.184 \pm .002$ & $.171 \pm .009$ & $.081 \pm .013$ & $.254 \pm .035$ & $\underline{\mathrm{NLS}} \underline{\mathrm{D}}$ \\
Proteins & $.368 \pm .075$ & $.362 \pm .024$ & $.297 \pm .039$ & $.013 \pm .008$ & $\underline{\mathrm{LSD}} \underline{\mathrm{N}}$ \\
Free amino acids & $.011 \pm .002$ & $.005 \pm .000$ & $.002 \pm .000$ & $.005 \pm .000$ & $\underline{\mathrm{L}} \underline{\mathrm{D}}$ \\
$\quad$ Total & .996 & 1.012 & .838 & 1.031 & $\underline{\mathrm{N}} \underline{\mathrm{SD}} \underline{\mathrm{L}}$ \\
Dry weight/wet weight & $.065 \pm .009$ & $.107 \pm .009$ & $.094 \pm .006$ & $.186 \pm .005$ &
\end{tabular}

Values are means \pm 1 standard error of three replicate samples. The last column summarizes interspecific rankings for each chemical component; letters that are underscored by the same line indicate species whose mucus is not significantly different in terms of the specific component $(\mathrm{N}=$ Nucella emarginata; $\mathrm{S}=$ Collisella scabra $; \mathrm{D}=$ Collisella digitalis $; \mathrm{L}=$ Lottia gigantea $)$.

Laboratory experiments. Species rankings of mucus persistence time in the laboratory were opposite from persistence times in the field. In the laboratory, trail mucus was more persistent $(P<.05)$ than stationary mucus. Lottia stationary mucus disappeared more rapidly than any other mucus type, whereas in the field Lottia stationary mucus was the most persistent (Table II).

\section{Bacterial growth}

The high variance and small sample size $(n=4)$ in this experiment precluded a statistically clear ranking of the mucus types in their effect on bacterial growth rates (Table I). Examining the overall trends, however, two points are evident. First, the trails of the homing species (Lottia and C. scabra) had higher bacterial growth rates than those of $C$. digitalis and Nucella. The difference between $C$. scabra and $C$. digitalis is significant $(P<.05)$. Second, mucus produced by stationary $C$. digitalis individuals promoted bacterial growth better than $C$. digitalis trail mucus. The correspondence among laboratory persistence studies, microalgal stimulation experiments, and bacterial growth studies indicates a positive correlation between the ability to enhance microalgal growth and the ability to stimulate bacterial growth.

\section{Biochemical characterization}

The results of the biochemical determinations are summarized in Table III. The pedal mucous secretions of all four gastropod species consisted primarily of water, ranging from an average of $81.4 \%$ water for Nucella to $93.5 \%$ water for Lottia. The difference in water content among species appears small; however, evaluating water content as grams of water to gram dry weight of mucus reveals that Nucella mucus contained $4.38 \mathrm{~g}$ water/g dry wt, while Lottia mucus consisted of $14.38 \mathrm{~g}$ water/g dry wt-almost 3.3 times as much water. The mucus of $C$. scabra ( $8.35 \mathrm{~g}$ water/g dry wt) and $C$. digitalis ( $9.64 \mathrm{~g}$ water/g dry wt) contained an intermediate amount of water.

The amounts of inorganics present in pedal mucus were not significantly different among the three limpet species, and ranged from $43 \%$ of dry weight in Lottia to $47 \%$ of dry weight in C. scabra. The mucus from the carnivore, Nucella, contained a substantially higher proportion of inorganics ( $75 \%$ dry weight). 
In all species, the lipid levels in pedal mucus were consistently less than $1 \%$ of the total dry weight.

Proteins and carbohydrates are the major organic components of pedal mucus. The carbohydrate concentrations in Lottia mucus (18.4\% dry weight) and C. scabra mucus $(17.1 \%$ dry weight $)$ are higher $(P<.05)$ than in $C$. digitalis mucus $(8.1 \%$ dry weight). There was a non-significant trend in protein content among the three limpet species, with the protein levels in $C$. digitalis mucus (29.7\% dry weight) somewhat lower than the protein content of Lottia (36.8\% dry weight) and C. scabra (36.2\% dry weight). The mucus of Nucella is clearly different from limpet mucus; its carbohydrate content is higher ( $25.4 \%$ dry weight) and its protein level (1.3\% dry weight) is significantly lower $(P<.05)$ than levels in limpet mucus.

The concentration of free amino acids in pedal mucus were higher in Lottia followed by C. scabra, and Nucella, and then by C. digitalis.

In summarizing the biochemistry results, it should be noted that on a dry weight basis, the mucus of homing limpet species (Lottia and C. scabra) contained more carbohydrate and protein than that of the non-homing, aggregating limpet, $C$. digitalis. This suggests that the mucus produced by Lottia and C. scabra is energetically more expensive to produce than the mucus of $C$. digitalis. Also, the mucus produced by the carnivorous Nucella was quantitatively different in several biochemical components from the mucus produced by the herbivorous limpets.

\section{DISCUSSION}

The sticky trails of all the investigated gastropod species effectively entrapped microalgae in the field. Because this ability was found in all the gastropods examined (not only the herbivores), it may be a side-effect of producing a mucus that is effective in allowing the animal to adhere to the substratum.

The ability of mucous trails to stimulate microalgal growth was seen only in the homing limpet species, Lottia and C. scabra. It is not surprising that Nucella does not produce trails that stimulate algal growth; it is a carnivore and would not benefit from this ability. However, herbivorous $C$. digitalis does not produce a provendering mucous trail. Differences in the ability of mucus to stimulate the growth of microalgae may be understood by examining interspecific differences in natural history and mucus energetic cost. The explanation, presented in detail elsewhere (Connor and Quinn, 1984), is essentially the following. Both Lottia and C. scabra invest more energy in mucus production than $C$. digitalis, but this high cost is defrayed by the enhancement of food levels. In order for this type of strategy to be effective, a species needs to be the primary consumer of its own high cost trails with their entrapped microalgae. Thus, there must be a separation of individuals and the mucus producer should remain in the area to allow retracing of its trails. Both Lottia and C. scabra meet these two requirements. Both maintain home scars, have restricted ranges, retrace their own mucous trails, and behave aggressively when encountering other limpets (Wright, 1977; Sutherland, 1970). In contrast, C. digitalis forms aggregations and individuals frequently follow trails of conspecifics. Such aggregations and a relatively unrestricted home range should prohibit a limpet from using the trophic benefits derived from a high cost mucus.

In addition to having smaller home ranges, both Lottia and C. scabra exhibit an interesting behavior which may be related to the possession of a provendering mucus. When these limpets move out of their home scars, they slowly circle the home scar by rotating their bodies back and forth. Usually a considerable amount of mucus is 
laid down on the rock near the home scar before the limpets slowly move away to forage. When grazing occurs near the scar, it usually is done during the return trip to the home scar. This behavioral sequence would be expected to promote algal enhancement near the home site. In contrast, when the non-homing limpet species, $C$. digitalis, starts to forage, it will move away from its resting place in a straight line; there is no behavior resulting in extra mucus deposition and $C$. digitalis generally does not forage near its resting place.

\section{Mucus persistence}

The field experiments indicate that mucus appears to last long enough in the high intertidal zone for the stimulation of microalgal growth to occur. Field persistence values may even be conservative because mucus may not last as long on Plexiglas as it lasts on a more porous surface, such as the actual rock surface. However, it also should be noted that in the laboratory, six to seven days were required to detect significant differences in algal growth under conditions of constant illumination and submergence. Although it can not be assumed that, as in the laboratory, only seven days are required in the field for significant algal growth enhancement by mucous trails, Sechler and Gundersen (1973) report that diatoms begin to show "active growth" on glass surfaces after five days of exposure to field conditions. In addition, the grazing patterns of both homing species suggest that seven days is a reasonable estimate of minimum useful persistence time. Both Lottia and C. scabra generally forage over different sections of their home ranges during each foraging period. Although there is considerable variation in foraging behavior, these limpets generally do not regraze an area for at least four to seven days.

Low mucus persistence time in the laboratory correlates positively with high rates of bacterial growth, supporting the conclusion that mucus disappearance in the laboratory is due to bacterial decomposition. Because certain types of mucus are more susceptible to bacteria growth (e.g., the stationary mucus and the trails of homing limpet species), it would seem reasonable to expect that these mucous secretions should break down faster under field conditions. In contrast to this expectation, the carbon particles used to mark mucus lasted longer on bacteria-enhancing mucus in the field.

This apparent contradiction may be explained by differences in the design of the laboratory and field experiments. In the laboratory, as mucus was broken down, the attached carbon particles immediately went into suspension because secretions were submerged continuously. In the field, at the high intertidal site, mucus was submerged for a maximum of four hours daily. Thus, as mucus was broken down by bacterial action, the particles were not immediately removed. The mucous film may have been replaced with a microbial film, and the carbon particles remained attached to this newly created film. The persistence of the carbon marker may not mean that limpet mucus was still present, but that some sort of adhesive film, replacing the limpet mucous film, had been produced by bacteria. Most marine bacteria produce an extracellular mucopolysaccharide while simultaneously decomposing existent organic films (Corpe, 1973; Sechler and Gundersen, 1973).

Mucus, or at least the carbon particles marking mucous trails, disappeared from intertidal site more rapidly than from the high intertidal site. This is probably fthe increased submergence time at the lower site. Increased submergence more time for sand scour and mechanical breakdown of mucus by wave action. Also, as indicated by the laboratory persistence experiments, increased sub- 
mergence times at the lower site would reduce the chance that carbon particles would remain attached to any developing microbial film. It is not known if mucus lasts long enough at this level for algal growth stimulation to occur, even though the algal biomass attached to all experimental and control surfaces was higher at the lower intertidal site. Microalgal biomass levels might be expected to be higher at the lower site because microalgal growth rates increase with decreasing tidal height (Castenholz, 1961; Nicotri, 1974).

At the low intertidal site, filters coated with the mucous trails from C. scabra had significantly less microalgae attached to them than those of the other two limpet species. This may reflect the quick disappearance of $C$. scabra trails at this site. Collisella scabra trails disappeared more quickly than any of the other limpet species, although the difference between $C$. scabra and Lottia was not significant. The reason for the faster disappearance of $C$. scabra trail mucus at the low site is not known, but it is interesting in light of the behavior of the limpets living at this tidal height. Individual $C$. scabra larvae settle throughout the intertidal region and juveniles $(<8 \mathrm{~mm})$ may be found at low intertidal sites. In the field, juveniles do not home (Hewatt, 1940), perhaps because mucous trails at lower intertidal levels do not persist long enough to enable homing. However, juvenile C. scabra (1-2 mm) have been observed to home under laboratory conditions (Charles Baxter, Hopkins Marine Station, Pacific Grove, California).

\section{Potential mechanisms of algal enhancement}

Algal growth enhancement is assumed because of the differences in chlorophyll levels found for the different types of mucus. The specific microalgal changes responsible for these differences in chlorophyll biomass are not known. Mucous secretions may increase the growth rates or reproductive rates of one or more microalgal species. Because most of the species in the cultures were diatoms, the biomass increases were probably due to an increase in the number of individuals rather than an increase in the size of existing individuals. Many diatom species do not increase in size following asexual reproduction and cell size is continually reduced (in a one-cell line) during successive bouts of asexual reproduction (Bold and Wynne, 1978).

Consistency among results of laboratory persistence studies, microalgal stimulation experiments, and bacterial growth studies indicates a positive correlation between the ability to enhance microalgal growth and the ability to stimulate bacterial growth. There are several possible explanations for the stimulation of both bacterial and algal growth by the mucous trails of homing limpet species. First, it is possible that bacterial and algal growth are stimulated by separate chemical components, or that a single component simultaneously stimulates the growth of both. Several species of littoral pennate diatoms, including Navicula and Nitzschia, are capable of heterotrophic growth when supplied with sources of carbon and nitrogen (Lewin, 1953; reviewed by Hellebust and Lewin, 1977); mucus could serve as such an organic substrate. Marine bacterial growth also is limited by the amount of organic carbon present in seawater (Jannasch, 1967; Sieburth, 1979), so mucus could significantly enhance bacterial growth.

Bacteria have shorter generation times than diatoms, and thus an increase in bacteria is detected sooner; however, the ability of mucus to enhance bacterial growth, and then algal growth, suggests that bacteria may be involved in the process of stimulating algal growth. The idea of a bacterial film facilitating the growth of microalgae is well established. Bacteria produce an extracellular mucous film that is a prerequi- 
site for the atrachment and growth of microalgae (Corpe, 1973; Sechler and Gundersen, 1973; Young and Mitchell, 1973; Haines and Guillard, 1974; Sieburth, 1979). Come 1973) and Marshall et al. (1971) suggest that this mucous film is produced to bind bacteria to the substrate. However, considerable amounts of metabolic residues accumulating within this microbial film provide adsorbed, but non-developing, diatoms with an enriched substrate for growth (Sechler and Gundersen, 1973). Corpe (1973) found that the microbial film is a polyanionic carbohydrate with the ability to complex both metal ions and aggregate particulate materials. The breakdown of mucus by bacterial enzymes would be expected to make the mucous surface a rich source of nutrients and an ideal substrate for further biological activity such as microalgal growth (Corpe, 1973; Dring, 1982). Bacteria may provide microalgae with a limiting nutrient, for example, vitamin B-12 (O’Kelley, 1974; Provasoli and Carlucci, 1974). Alternatively, bacterial decomposition of limpet mucus might make the nutritional components of the mucus readily available for algal use. The intermediary role played by bacteria seems likely in the present study if the persistence of the carbon marker on mucus at the high intertidal field site was due to the replacement of limpet mucous trails by bacterial films.

Regardless of whether bacteria are necessary precursors for microalgal growth enhancement, there must be some differences in the mucus of the homing limpet species that are responsible for the observed provendering action. The biochemical analysis provides some possible explanations. The significant ability of Nucella mucus to entrap algae, but not stimulate microalgal growth, suggests that two distinct mechanisms are responsible for the adhesion and stimulation effects.

The ability of mucous secretions to adhesively attach microalgae is correlated with mucus carbohydrate content. That is, Lottia, C. scabra, and Nucella all produce trails that are stickier than $C$. digitalis in terms of algal adhesion rates and the mucus produced by Lottia, C. scabra, and Nucella also contains significantly more carbohydrate than the mucus of $C$. digitalis. There are polyanionic carbohydrate residues in gastropod pedal mucus (Denny, 1979). If an increase in carbohydrate content results in an increase in these polyanionic residues, an increased attraction of charged particles to pedal mucus might be expected. However, changing the concentration of a polymer may change it from being an adhesive to a dispersant (Hermans, 1983). Thus an adhesive role can not be assigned to a secretory product strictly on the basis of its chemical characteristics (Hermans, 1983). The chemical analysis presented here is meant to be preliminary; much more work is needed to define the chemical composition of pedal mucus and the relationship between ionic interactions and adhesion.

The ability of homing limpet species to produce algal growth stimulating trails is not related easily to the concentration of any specific component. The high carbohydrate content of the non-stimulating mucus of Nucella suggests that carbohydrate concentration alone cannot be responsible for algal growth enhancement effects. Protein levels are higher in the mucus of homing species, but this difference is not significant, again suggesting that this component may not be responsible for algal growth enhancement. On a dry weight basis, the mucus of homing limpet species contains more organics than non-homing species. This difference among mucus types may be responsible for species differences in microalgal stimulation. Both bacteria (Jannasch, ) and diatoms (Lewin, 1953) can grow more rapidly when the concentrations of in organic substrates are increased. The inability of the mucus of Nucella and alis to significantly enhance microalgal growth may be due to relatively low f organics in their mucus. However, all types of mucus contain organics, astropods with relatively low amounts of organics might be expected to 
increase microalgal growth, but this was not observed. This suggests that some other component contained only in the mucus of homing limpets is involved.

Comparison of mucus composition on a dry weight basis may be misleading because of the significant species differences in mucus dry weight/wet weight. These differences suggest that it is more appropriate to look for chemical components that vary in proportion wet weight in ways corresponding to the patterns seen for microalgal adhesion and stimulation. However, this assumes that for all gastropod species a given weight of mucus covers a constant area of substrate, and this often is not true (Connor, 1983). Also, because the wet weight of mucus depends on the conditions of collection (Connor, unpub. data), dry weight comparisons probably are more accurate than wet weight comparisons.

\section{Environmental variability}

Another important consideration is the type of environment a species typically inhabits. Mucus may not last long enough in low intertidal sites or in sites of high wave energy and scour to effectively enhance food resources, although homing species do occur in these environments. It is noteworthy that Lottia does not exhibit territoriality in areas of high sand scour (Betsy Steele, University of California, Santa Cruz).

The differences between and within laboratory and field results obtained during this study emphasize the potential importance of environmental conditions on the various properties of mucus. In order to understand better the contributions of pedal mucus to a gastropod's energy budget, mucus provendering needs to be examined under a wide range of field conditions.

A serendipitous demonstration of the importance of water column characteristics on the rates of microalgal entrapment was obtained during the one-day field adhesion experiment. More microalgae were found adhering to mucous trails after one day than after seven days (Table I). This apparent contradiction of the ability of mucus to enhance microalgal biomass levels probably was due to differences in the density of phytoplankton within the water column between the two experimental periods. An algal bloom occurred during the one-day experiment (the water column was visibly green), while "normal" phytoplankton densities were present during the sevenday experiment. Mucous trails may allow limpets to use a phytoplankton bloom as an additional food resource.

\section{Occurrence of provendering mucus}

The ability of mucous secretions to stimulate the growth of potential food species is not unique to intertidal limpets. Calow (1974) documented that mucus plays a provendering role for the pulmonate Planorbis contortus $\mathrm{L}$. The mucous trails of $P$. contortus were found to stimulate the growth of bacterial species which are ingested preferentially by $P$. contortus. The prosobranch Hydrobia ventrosa also is thought to use secreted mucus to trap bacteria (Kofoed, 1975a). Growth efficiency is higher in Hydrobia when bacteria are included in the diet (Kofoed, 1975b). Calow (1979) has outlined the circumstances when the production of a high energy provendering mucus would be adaptive. Essentially, the producer and the consumer of the mucus must be related. This can be ensured by a variety of mechanisms, including those demonstrated by Lottia and C. scabra, namely site specificity and site defense. Thus for limpets, the ability to enhance food resources seems to be related to the homing habit. 
It is not known whether any other homing species use mucous trails to stimulate the growth of food species. Homing behavior depends on many factors and the homing response varies extensively even within a single species. Frequently, juvenile limpets do not home, but adults home consistently (Branch, 1981). Many gastropods and chitons have restricted microhabitats or small home ranges, and yet do not home in the strict sense of returning to precisely the same spot. The results of studies on the proportion of a limpet population showing strict homing behavior vary considerably, even when study is restricted to a single species (for the species included in this study see Hewatt, 1940; Villee and Groody, 1940; Brant, 1950; Frank, 1964; Galbraith, 1965; Jessee, 1968; Stimson, 1970; Sutherland, 1970). It is the general consensus that adult Lottia and C. scabra consistently home, but that any movement pattern for $C$. digitalis is far less regular, with movement apparently affected by both seasonal (Frank, 1964) and density-dependent factors (Breen, 1972, 1973). In spite of this variability in homing response, several gastropod and chiton species generally are considered to home. This homing response would allow the production of a highcost, provendering mucus.

In a more general sense, mucus stimulation of bacterial and microalgal growth could be important for any organism that relies on mucus to aid in feeding. Most suspension feeders that use mucous nets are the sole consumers of their mucus; the ability of mucus to collect and stimulate the growth of entrapped food species could be exploited by the animal if the mucous traps were collected and consumed at a time that maximizes net energetic returns.

\section{ACKNOWLEDGMENTS}

Several people deserve thanks and recognition for their advice and assistance during the course of this study. K. Rice, J. F. Quinn, and J. Maron all helped with field work. J. H. Crowe and N. Scherer provided indispensable insights during the biochemistry studies. D. R. Lindberg shared his thoughts on limpet homing behavior and introduced me to San Nicolas Island. K. Rice, J. F. Quinn, D. W. Phillips, J. H. Crowe, and two anonymous reviewers made valuable comments on earlier drafts of this manuscript. This study was supported by a University of California JastroShields Research Scholarship.

\section{LITERATURE CITED}

ABbott, D. P., AND E. C. HAderlie. 1980. Prosobranchia: marine snails. Pp. 230-308 in Intertidal Invertebrates of California, R. H. Morris, D. P. Abbott and E. C. Haderlie, eds. Stanford University Press, Stanford.

Baumann, P., AND L. Baumann. 1980. The marine gram-negative eubacteria: genera Photobacterium, Beneckea, Alteromonas, Pseudomonas, and Alcaligenes. Pp. 1302-1331 in The Prokaryotes, Vol. II, M. P. Starr, H. Stolp, H. G. Truper, A. Balows, and H. G. Schlegel, eds. Springer Verlag, New York.

Bold, H. C., AND M. J. Wynne. 1978. Introduction to the Algae: Structure and Reproduction. PrenticeHall, Inc., New Jersey. 760 pp.

BRADFORD, M. 1976. A rapid and sensitive method for the quantitation of microgram quantities of protein utilizing the principles of protein-dye binding. Analyt. Biochem. 72: 248.

BRAivch, G. M. 1981. The biology of limpets: physical factors, energy flow, and ecological interactions. Oceanogr. Mar. Biol. Ann. Rev. 19: 235-380.

BRANT, D. H. 1950. A quantitative study of the homing behavior of the limpet Acmaea scabra. Special Problems in Marine Biology Reports (unpublished). University of California, Berkeley.

BREEN, P. A. 1972. Homing behavior and population regulation in the limpet Acmaea (Collisella) digitalis. Veliger 14: 177-183. 
BREEN, P. A. 1973. Seasonal migration and population regulation in the limpet Acmaea (Collisella) digitalis. Veliger 15: 133-141.

CALOw, P. 1974. Some observations on locomotory strategies and their metabolic effects in two species of freshwater gastropods. Oecologia 16: 149-161.

CALOW, P. 1979. Why some metazoan mucus secretions are more susceptible to microbial attack than others. Am. Nat. 114: 149-152.

Castenholz, R. W. 1961. The effect of grazing on marine littoral diatom populations. Ecology 42: 783794.

CONNOR, V. M. 1983. The roles of mucous trails in the ecology of intertidal limpets: growth enhancement of algal food species and chemical communication. Ph.D. Thesis, University of California, Davis.

CONnOR, V. M., AND J. F. QUINN. 1984. Stimulation of food species growth by limpet mucus. Science 225: $843-844$.

CORPE, W. A. 1973. Microfouling: the role of primary film forming marine bacteria. Pp. 598-609 in Proc. 3rd Int. Congress on Marine Corrosion and Fouling, R. F. Acker, ed. Northwestern University Press, Evanston.

DENNY, M. 1979. The role of mucus in the locomotion and adhesion of the pulmonate slug Ariolimax columbianus. Ph.D. thesis University of British Columbia.

DENNY, M. 1980a. The role of gastropod pedal mucus in locomotion. Nature 285: 160-161.

DENNY, M. 1980b. Locomotion: the cost of gastropod crawling. Science 208: 1288-1290.

DRING, M. J. 1982. The Biology of Marine Plants. Edward Arnold Limited, London.

Frank, P. W. 1964. On home range of limpets. Am. Nat. 98: 99-104.

Galbraith, R. T. 1965. Homing behavior in the limpets Acmaea digitalis and Lottia gigantea. Am. Midl. Nat. 74: 245-246.

GRENON, J.-F., AND G. WALKER. 1980. Biochemical and rheological properties of the pedal mucus of the limpet, Patella vulgata L. Comp. Biochem. Physiol. 66B: 451-458.

HaINES, K. C., AND R. R. L. GuIllaRD. 1974. Growth of vitamin B-12 requiring marine diatoms in mixed laboratory cultures with vitamin B-12 producing marine bacteria. J. Phycol. 10: 245-252.

HARROLD, C. 1982. Escape responses and prey availability in a kelp forest predator-prey system. Am. Nat. 119: $132-135$

Hellebust, J. A., AND J. Lewin. 1977. Heterotrophic nutrition. Pp. 169-197 in The Biology of Diatoms. D. Werner, ed. University of California Press, Berkeley.

Hermans, C. O. 1983. The duo-gland adhesive system. Oceanogr. Mar. Biol. Ann. Rev. 21: 283-339.

Hewatt, W. G. 1940. Observations on the homing limpet Acmaea scabra Gould. Am. Nat. 24: $205-208$.

JANNASCH, H. W. 1967. Growth of marine bacteria at limiting concentrations of organic carbon in seawater. Limnol. Oceanogr. 12: 264-271.

JESSEE, W. F. 1968. Studies of the homing behavior in the limpet Acmaea scabra. Veliger 11(suppl.): 5255 .

Keleti, G., AND W. H. Lederer. 1973. Handbook of Micromethods for the Biological Sciences. Van Nostrand Reinhold Company, New York.

KOFOED, L. H. 1975a. The feeding biology of Hydrobia ventrosa. I. The assimilation of different components of the food. J. Exp. Mar. Biol. Ecol. 19: 233-241.

KOFOED, L. H. 1975b. The feeding biology of Hydrobia ventrosa. II. Allocation of the components of the carbon-budget and the significance of the secretion of dissolved organic materials. J. Exp. Mar. Biol. Ecol. 19: 243-256.

Kunz, C., AND V. M. ConNor. 1986. Functions of the home scar of the limpet Collisella scabra (Gould) (Gastropoda: Acmaeidae). Veliger 29: 25-30.

LEWIN, J. C. 1953. Heterotrophy in diatoms. J. Gen. Microbiol. 9: 305-313.

LINDBERG, D. R., AND K. R. DWYER. 1983. The topography, formation, and role of the home depression of Collisella scabra (Gould). Veliger 25: 229-234.

Marshall, K. C., R. Stout, AND R. Mitchell. 1971. Mechanism of the initial event in the sorption of marine bacteria to surfaces. J. Gen. Microbiol. 68: 337-348.

MCFARLANE, I. D. 1981. In the intertidal homing gastropod Onchidium verruculatum (Cuv.) the outward and homeward trails have a different information content. J. Exp. Mar. Biol. Ecol. 51: 207-218.

Nicotri, M. E. 1974. Resource partitioning, grazing activities and influence on the microflora by intertidal limpets. Ph.D. Thesis, University of Washington, Seattle.

NoRth, B. B. 1975. Primary amines in California coastal waters: utilization by phytoplankton. Limnol. Oceanogr. 20: 20-27.

O’Kelley, J. C. 1974. Inorganic nutrients. Pp. 610-635 in Algal Physiology and Biochemistry, W. D. P. Stewar, ed. Blackwell Scientific Publications, Oxford.

Provasoli, L., AND A. F. CARLUCCI. 1974. Vitamins and growth regulators. Pp. 741-787 in Algal Physiology and Biochemistry, W. D. P. Stewar, ed. Blackwell Scientific Publications, Oxford. 
SCHW antzkofe, S., T. MurPHy, AND S. BLACK. 1983. Independent Investigations in Introductory Biol3rd ed. Burgess Publishing Company, Minneapolis.

SECritz. E. AND K. GUNDERSEN. 1973. Role of surface chemical composition on the microbial contribution to primary films. Pp. 610-616 in Proc. 3rd Int. Congress on Marine Corrosion and Fouling, R. F. Acker, ed. Northwestern University Press, Evanston.

StBtex, J. 1982. A study of homing in the owl limpet, Lottia gigantea (Sowerby), by analyzing its movements in an experimental pool. M.S. Thesis, San Diego State University.

Sibiurth, J. M. 1979. Sea Microbes. Oxford University Press, New York.

STIMSON, J. 1970. Territorial behavior of the owl limpet Lottia gigantea. Ecology 51: 113-118.

Stimson, J. 1973. The role of the territory in the ecology of the intertidal limpet Lottia gigantea (Gray). Ecology 54: 1020-1030.

Strickland, J. D. H., AND T. R. PARSONS. 1968. A practical handbook of seawater analysis, 2nd ed. Bull. Fish. Res. Board. Can. 167.

Sutherland, J. 1970. Dynamics of high and low populations of the limpet Acmaea scabra. Ecol. Monogr. 40: $169-188$.

VilleE, C. A., AND T. C. Groody. 1940. The behavior of limpets with reference to their homing instinct. Am. Midl. Nat. 24: 190-204.

WELLS, R. A. 1980. Activity pattern as a mechanism of predator avoidance in two species of acmaeid limpet. J. Exp. Mar. Biol. Ecol. 48: 151-168.

Wolcott, T. G. 1973. Physiological ecology and intertidal zonation in limpets (Acmaea): a critical look at "limiting factors." Biol. Bull. 145: 389-422.

WRIGHT, W. G. 1977. Avoidance and escape: two responses of intertidal limpets to the presence of the territorial owl limpet Lottia gigantea. Abstract of paper presented at the Western Society of Naturalists, 58th Annual Meeting. p. 50.

YounG, L. Y., AND R. MiTCHELl. 1973. The role of chemotactic response in primary microbial film formation. Pp. 617-624 in Proc. 3rd Int. Congress on Marine Corrosion and Fouling, R. F. Acker, ed. Northwestern University Press, Evanston.

ZAR, J. H. 1974. Biostatistical Analysis. Prentice-Hall, Inc., Englewood Cliffs. 620 pp. 


\section{$2 \mathrm{BHL}$ Biodiversity Heritage Library}

Connor, Valerie M. 1986. "THE USE OF MUCOUS TRAILS BY INTERTIDAL LIMPETS TO ENHANCE FOOD RESOURCES." The Biological bulletin 171, 548-564. https://doi.org/10.2307/1541623.

View This Item Online: https://www.biodiversitylibrary.org/item/17196

DOI: https://doi.org/10.2307/1541623

Permalink: https://www.biodiversitylibrary.org/partpdf/33788

\section{Holding Institution}

MBLWHOI Library

\section{Sponsored by}

MBLWHOI Library

\section{Copyright \& Reuse}

Copyright Status: In copyright. Digitized with the permission of the rights holder.

License: http://creativecommons.org/licenses/by-nc-sa/3.0/

Rights: https://biodiversitylibrary.org/permissions

This document was created from content at the Biodiversity Heritage Library, the world's largest open access digital library for biodiversity literature and archives. Visit BHL at https://www.biodiversitylibrary.org. 